\title{
Pseudoalteromonas marina sp. nov., a marine bacterium isolated from tidal flats of the Yellow Sea, and reclassification of Pseudoalteromonas sagamiensis as Algicola sagamiensis comb. nov.
}

Correspondence Jin-Woo Bae baejw@kribb.re.kr

\author{
Young-Do Nam, ${ }^{1,4}$ Ho-Won Chang, ${ }^{1}$ Ja Ryeong Park, ${ }^{1}$ Hyuk-Yong Kwon, ${ }^{1}$ \\ Zhe-Xue Quan, ${ }^{2}$ Yong-Ha Park, ${ }^{3}$ Jung-Sook Lee, ${ }^{1}$ Jung-Hoon Yoon ${ }^{1}$ \\ and Jin-Woo Bae $\mathrm{Ba}^{1,4,5}$ \\ ${ }^{1}$ Biological Resource Center, KRIBB, Daejeon 305-806, Korea \\ ${ }^{2}$ Fudan University, Shanghai 200433, China \\ ${ }^{3}$ Yeungnam University, Gyeongsangbuk-do 712-749, Korea \\ ${ }^{4}$ University of Science and Technology, Daejeon 305-333, Korea \\ ${ }^{5}$ Environmental Biotechnology National Core Research Center, Gyeongsang National University, \\ Jinju 660-701, Korea
}

\begin{abstract}
Two Gram-negative, motile and strictly aerobic marine bacteria were isolated from a tidal flat sediment sample obtained from Dae-Chun, Chung-Nam, Korea. They were preliminarily identified as Pseudoalteromonas-like bacteria, based on 16S rRNA gene sequence analysis showing nearly identical sequences ( $>99.7 \%$ sequence similarity) and the highest similarity ( $98.4 \%$ ) to the species Pseudoalteromonas undina. Some phenotypic features of the newly isolated strains were similar to those of members of the genus Pseudoalteromonas, but several physiological and chemo-taxonomical properties readily distinguished the new isolates from previously described species. DNA-DNA hybridization with type strains of phylogenetically closely related species demonstrated that the isolates represent a novel Pseudoalteromonas species, for which the name Pseudoalteromonas marina sp. nov. is proposed, with the type strain mano4 ${ }^{\top}(=\mathrm{KCTC}$ $12242^{\top}=\mathrm{DSM} 17587^{\top}$ ). In addition, on the basis of this study and polyphasic data obtained from previous work, it is proposed that the species Pseudoalteromonas sagamiensis should be reclassified as Algicola sagamiensis comb. nov. and that strain B-10-31 ${ }^{\top}$ (=DSM $14643^{\top}=\mathrm{JCM}$ $11461^{\top}$ ) be designated the type strain.
\end{abstract}

The genus Pseudoalteromonas (type genus of the family Pseudoalteromonadaceae) (Gauthier et al., 1995; Ivanova et al., 2004a) currently comprises 34 recognized species, with Pseudoalteromonas haloplanktis as the type species. Many Pseudoalteromonas species have been isolated from the marine environment and show interstrain 16S rRNA gene sequence similarity values ranging from 90 to $99.9 \%$. To better describe the Pseudoalteromonas community associated with the tidal flats along the Korean coast (Kim et al., 2004), marine sediment was sampled and its bacterial diversity was investigated. Here, we describe two novel Pseudoalteromonas-like strains, which were determined to belong to the genus Pseudoalteromonas on the basis of their $16 \mathrm{~S}$ rRNA gene sequences. Accordingly, the objective of the

The GenBank/EMBL/DDBJ accession numbers for the 16S rRNA gene sequences of strains mano $4^{\top}$ and mano6 are AY563031 and AY563032, respectively. present work was to elucidate the taxonomic position of these newly isolated strains, designated mano $4^{\mathrm{T}}$ and mano6, via phenotypic, genetic and chemo-taxonomic analyses. An additional aim was to determine whether the current taxonomic status of Pseudoalteromonas sagamiensis is appropriate.

Strains mano $4^{\mathrm{T}}$ and mano6 were isolated from a tidal flat area of Dae-Chun, Chung-Nam, Korea ( $36^{\circ} 17^{\prime} 45.2^{\prime \prime} \mathrm{N} 126^{\circ}$ $31^{\prime} 9.5^{\prime \prime}$ E) using the dilution plating technique on marine agar 2216 (MA; Difco). The two strains were grown routinely at $25{ }^{\circ} \mathrm{C}$ for 3 days. Their closest relatives, as judged by $16 \mathrm{~S}$ rRNA gene similarity, were Pseudoalteromonas undina DSM $6065^{\mathrm{T}}$, Pseudoalteromonas translucida DSM $14402^{\mathrm{T}}$ and Pseudoalteromonas aliena DSM $16473^{\mathrm{T}}$. These three strains were obtained from DSMZ, Germany, and were grown under the same conditions and used as reference strains. Cultures of the isolates and the reference strains were stored at $-80^{\circ} \mathrm{C}$ in 


\section{Table 1. Phenotypic characteristics that distinguish $P$. marina sp. nov. mano $4^{\top}$ from other species of the genus Pseudoalteromonas}

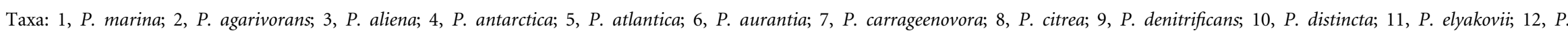

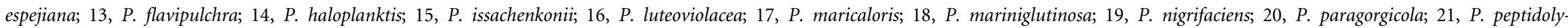

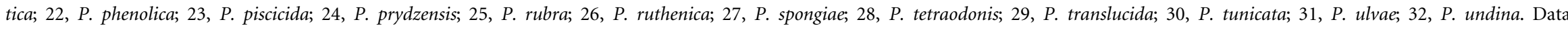

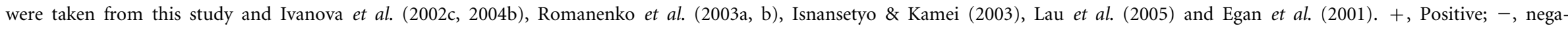
tive; $+/-$, variable reaction; $\mathrm{w}$, weak reaction; $\mathrm{ND}$, no data available.

\begin{tabular}{|c|c|c|c|c|c|c|c|c|c|c|c|c|c|c|c|c|c|c|c|c|c|c|c|c|c|c|c|c|c|c|c|c|}
\hline Characteristic & 1 & 2 & 3 & 4 & 5 & 6 & 7 & 8 & 9 & 10 & 11 & 12 & 13 & 14 & 15 & 16 & 17 & 18 & 19 & 20 & 21 & 22 & 23 & 24 & 25 & 26 & 27 & 28 & 29 & 30 & 31 & 32 \\
\hline $\begin{array}{l}\text { DNA G }+ \text { C } \\
\text { content }(\mathrm{mol} \%)\end{array}$ & 41.2 & 43.8 & 41.1 & 42.3 & 42.1 & 44.1 & 42 & 42.1 & 36.7 & 43.6 & 40 & 42.7 & 41.7 & 43.3 & 43 & 42 & 39.1 & 40.3 & 41.7 & 41.1 & 37.9 & 40.3 & 42.7 & 39 & 39 & 48.4 & 40.6 & 42.14 & 46.3 & 42 & ND & 42.2 \\
\hline Flagellation ${ }^{\star}$ & $\mathrm{P}$ & $\mathrm{P}$ & $\mathrm{P}$ & $\mathrm{P}$ & $\mathrm{P}$ & $\mathrm{P}$ & $\mathrm{P}$ & $\mathrm{P}$ & $\mathrm{P}$ & $\mathrm{P}, \mathrm{L}$ & $\mathrm{P}$ & $\mathrm{P}$ & $\mathrm{P}$ & $\mathrm{P}$ & $\mathrm{P}$ & $\mathrm{P}$ & $\mathrm{P}$ & $\mathrm{P}$ & $\mathrm{P}$ & $\mathrm{P}$ & $\mathrm{P}$ & $\mathrm{P}$ & $\mathrm{P}$ & $\mathrm{P}$ & $\mathrm{P}$ & $\mathrm{P}$ & - & $\mathrm{P}$ & B & $\mathrm{P}$ & $\mathrm{P}$ & $\mathrm{P}$ \\
\hline Pigmentation & - & - & + & - & - & + & - & + & + & + & - & - & + & - & - & + & + & - & + & + & + & + & + & - & + & + & - & - & - & + & + & - \\
\hline \multicolumn{33}{|l|}{ Growth at/in: } \\
\hline $4{ }^{\circ} \mathrm{C}$ & + & - & + & + & + & + & + & - & + & - & + & $+1-$ & - & - & + & - & - & - & + & + & - & - & - & + & - & - & - & + & + & + & + & + \\
\hline $37^{\circ} \mathrm{C}$ & + & - & - & - & - & - & + & - & - & - & + & + & + & - & + & + & + & + & - & - & + & + & + & - & + & + & + & - & - & - & - & - \\
\hline $1 \% \mathrm{NaCl}$ & - & + & - & + & - & + & + & + & + & + & + & + & + & + & + & - & + & + & + & + & + & + & + & + & - & + & - & + & + & + & + & + \\
\hline $3-6 \% \mathrm{NaCl}$ & + & + & - & + & + & + & + & + & + & + & + & + & + & + & + & + & + & + & + & + & + & + & + & + & + & + & + & + & + & + & - & + \\
\hline $8 \% \mathrm{NaCl}$ & + & + & - & + & - & + & + & + & - & - & + & + & + & + & + & - & + & + & + & - & + & - & + & + & - & + & - & + & + & + & - & + \\
\hline $10 \% \mathrm{NaCl}$ & + & - & - & + & - & - & + & + & - & - & + & + & + & + & + & - & + & - & + & - & - & - & + & + & - & - & - & + & - & + & - & + \\
\hline $12 \% \mathrm{NaCl}$ & + & - & - & - & $+1-$ & - & + & - & - & - & - & + & + & + & + & - & - & - & - & - & - & - & - & + & - & - & - & + & - & - & - & + \\
\hline $15 \% \mathrm{NaCl}$ & - & - & - & - & - & - & - & - & - & - & - & - & - & - & + & - & - & - & - & - & - & - & - & + & - & - & - & - & - & - & - & - \\
\hline \multicolumn{33}{|l|}{ Production of: } \\
\hline Amylase & + & + & + & - & + & + & - & + & + & - & + & + & + & + & - & + & + & + & + & + & + & + & + & + & + & + & - & - & + & + & ND & + \\
\hline Caseinase & + & + & + & + & + & - & + & + & + & + & + & + & + & + & + & + & + & + & + & + & + & ND & + & ND & + & + & ND & + & + & + & ND & + \\
\hline Alginase & + & + & + & ND & + & - & + & $\mathrm{ND}$ & + & + & + & + & $\mathrm{ND}$ & - & + & $\mathrm{ND}$ & + & + & + & $\mathrm{ND}$ & ND & - & $\mathrm{ND}$ & - & $\mathrm{ND}$ & + & - & $\mathrm{ND}$ & + & $\mathrm{ND}$ & - & - \\
\hline Agarase & - & + & + & - & + & - & - & - & - & - & - & - & - & - & - & - & - & + & - & - & - & - & - & - & - & - & - & - & - & - & + & - \\
\hline Chitinase & - & - & $\mathrm{ND}$ & - & - & - & - & - & + & - & - & - & + & $+1-$ & + & - & - & - & - & - & - & - & - & + & - & - & $\mathrm{ND}$ & - & - & - & $\mathrm{ND}$ & + \\
\hline DNase & + & + & $\mathrm{ND}$ & $+1-$ & + & + & + & + & + & + & + & + & + & + & + & + & + & + & + & + & + & + & + & - & + & + & + & + & + & + & $\mathrm{ND}$ & + \\
\hline \multicolumn{33}{|l|}{ Utilization of: } \\
\hline D-Glucose & + & $\mathrm{W}$ & $\mathrm{W}$ & + & + & + & + & + & + & + & + & + & + & + & + & + & + & $\mathrm{W}$ & + & $\mathrm{ND}$ & + & + & + & + & + & + & + & + & - & + & + & + \\
\hline D-Arabinose & - & - & - & $\mathrm{ND}$ & ND & - & ND & - & - & ND & ND & $\mathrm{ND}$ & - & $\mathrm{ND}$ & ND & - & + & + & ND & + & - & - & - & $\mathrm{ND}$ & - & - & - & ND & + & - & - & $\mathrm{ND}$ \\
\hline D-Galactose & - & - & - & - & + & - & - & - & $\mathrm{ND}$ & - & + & + & - & $+1-$ & + & - & + & + & + & + & - & - & + & $+1-$ & - & - & - & + & + & + & $\mathrm{ND}$ & - \\
\hline Maltose & + & + & $\mathrm{w}$ & + & + & - & + & - & + & - & + & + & + & + & + & - & + & + & + & + & + & + & - & + & + & - & + & + & - & - & + & + \\
\hline Melibiose & + & - & - & + & + & - & + & - & ND & + & - & + & - & - & + & - & + & - & + & - & - & - & - & - & - & - & - & - & - & - & - & - \\
\hline Lactose & - & - & ND & + & + & - & + & + & - & + & - & + & - & - & + & - & + & - & + & - & + & - & - & - & - & - & - & - & - & - & - & - \\
\hline D-Mannitol & - & - & $\mathrm{w}$ & + & + & - & + & - & - & - & + & $+1-$ & - & $+1-$ & + & - & + & + & $+1-$ & + & - & - & - & + & - & - & - & - & + & - & $\mathrm{ND}$ & $+1-$ \\
\hline Sorbitol & - & $\mathrm{ND}$ & - & - & - & - & - & - & - & - & - & - & - & - & - & - & + & $\mathrm{ND}$ & - & - & - & - & - & - & - & - & - & - & $\mathrm{ND}$ & - & - & - \\
\hline Citrate & - & - & - & + & + & - & + & - & ND & + & - & + & + & + & + & - & + & + & + & - & - & - & + & + & - & - & - & + & - & - & + & - \\
\hline Xylose & - & - & - & ND & - & - & - & - & ND & - & + & + & - & - & - & - & - & - & + & ND & $\mathrm{ND}$ & - & - & - & - & - & - & - & - & - & - & - \\
\hline L-Tyrosine & + & $\mathrm{ND}$ & - & $\mathrm{ND}$ & - & - & + & + & + & - & - & + & + & + & $\mathrm{ND}$ & $\mathrm{ND}$ & - & $\mathrm{ND}$ & + & - & $\mathrm{ND}$ & - & $\mathrm{ND}$ & $+1-$ & - & - & $\mathrm{ND}$ & + & $\mathrm{ND}$ & $\mathrm{ND}$ & $\mathrm{ND}$ & + \\
\hline
\end{tabular}




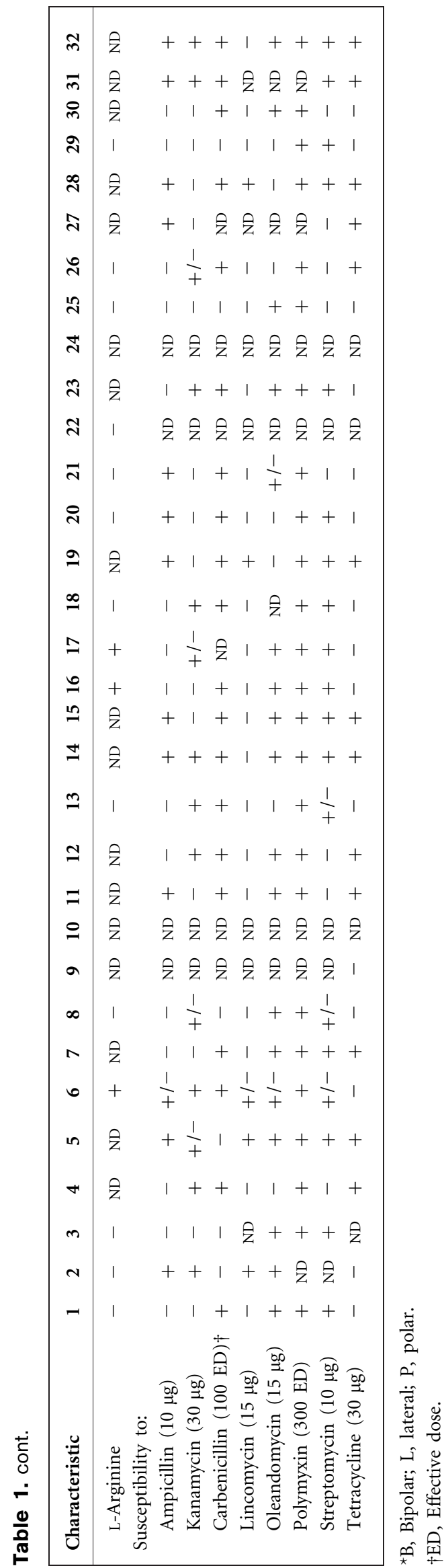

marine broth $(\mathrm{MB})$ containing $20 \%$ glycerol. For morphological and physiological characterization, strains mano $4^{\mathrm{T}}$ and mano6 and the reference strains were generally cultivated in $\mathrm{MB}$ with shaking at $25^{\circ} \mathrm{C}$. API 20NE and API ZYM test strips (bioMérieux) were used to analyse the biochemical and physiological traits of these bacterial strains. Strips were inoculated with a heavy bacterial suspension in ASW or AUX medium (bioMérieux), supplemented with $2 \%(\mathrm{w} / \mathrm{v})$ sea salts. Other biochemical tests were performed using the methods and media described by Gordon et al. (1973). Catalase activity was determined by bubble production in a $3 \%(\mathrm{v} / \mathrm{v})$ hydrogen peroxide solution. Growth under anaerobic conditions was determined microscopically (Nikon E600) after incubation for 7 days in anaerobic Gaspak jars (BBL) containing an atmosphere of $80 \% \mathrm{~N}_{2}, 10 \% \mathrm{CO}_{2}$ and $10 \% \mathrm{H}_{2}$ (by vol.). Growth at various $\mathrm{NaCl}$ concentrations and at various temperatures and $\mathrm{pH}$ values was measured in MB. Cellular morphology and the presence of spores were also determined microscopically. Cellular motility for the novel isolate was examined using fresh wet-mounts of young bacterial cultures in MB. For TEM, cells from exponentially growing cultures were negatively stained with $1 \%(\mathrm{w} / \mathrm{v})$ phosphotungstic acid. After air-drying, the grid was examined using a model $\mathrm{H}-7600$ transmission electron microscope (Hitachi). Results from the biochemical and physiological tests are given in Table 1 and in the species description. The new isolates could be readily differentiated from other closely related species by several phenotypic properties, as shown in Table 1.

Bacterial strains grown on MA for 3 days at $25^{\circ} \mathrm{C}$ were used for the analysis of fatty acid methyl esters. The fatty acid methyl esters were extracted and prepared according to standard protocols provided by the MIDI/Hewlett Packard Microbial Identification system (Sasser, 1990). Chromosomal DNA was extracted and purified as described by Sambrook et al. (1989). DNA G + C content was assessed by using the methods described by Tamaoka \& Komagata (1984). DNA was hydrolysed and the resultant nucleotides were analysed via HPLC using a reversed-phase column (Supelcosil LC-18-S; Supelco). Amplification, sequencing and phylogenetic analysis of the 16S rRNA gene were performed according to the methods described by Ivanova et al. (2002c). DNA-DNA hybridization was performed fluorometrically by using the method of Bae et al. (2005) with Cy5-labelled DNA probes and microarrays.

Phylogenetic trees based on 16S rRNA gene sequences of members of the genus Pseudoalteromonas showed that strains $\operatorname{mano}^{\mathrm{T}}$ and mano6 fall within the cluster of Pseudoalteromonas species (Fig. 1). Strains mano4 ${ }^{\mathrm{T}}$ and mano6 exhibited 16S rRNA gene sequence similarities of $92.8-98.4 \%$ to the type strains of 34 other Pseudoalteromonas species.

DNA-DNA hybridization studies were performed to determine the genomic relationship between strains mano ${ }^{\mathrm{T}}$ and mano6 and their three closest relatives, $P$. 


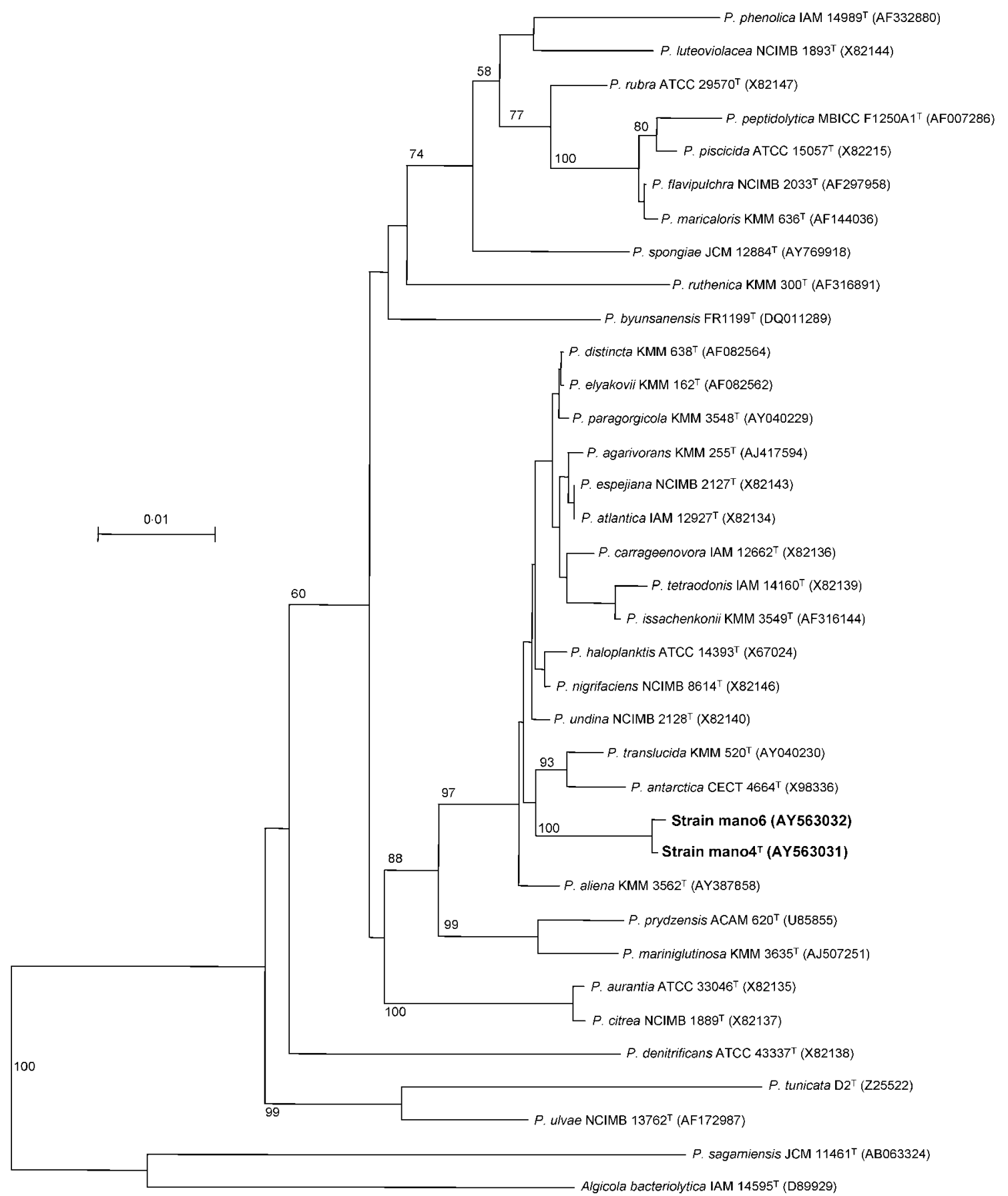

Fig. 1. Consensus phylogenetic tree based on $16 \mathrm{~S}$ rRNA gene sequences showing the relationship between strains mano $4^{\top}$ and mano6 and the type strains of other Pseudoalteromonas species. The tree was constructed based on the neighbourjoining method. Bootstrap analyses were performed with 1000 repetitions (only values greater than $50 \%$ are shown). GenBank accession numbers are shown in parentheses. Bar, 1 substitution per 100 nucleotide positions.

undina DSM $6065^{\mathrm{T}}$, P. translucida DSM $14402^{\mathrm{T}}$ and $P$. aliena DSM $16473^{\mathrm{T}}$, in terms of $16 \mathrm{~S}$ rRNA gene similarity. We observed a mean level of $88 \%$ DNA-DNA relatedness between strains mano $4^{\mathrm{T}}$ and mano6. The levels of DNADNA relatedness between strain mano $4^{\mathrm{T}}$ and its three closest relatives were all less than $4 \%$. Considering the phenotypic, phylogenetic and genotypic characteristics of the isolates, we concluded that strains mano $4^{\mathrm{T}}$ and mano6 belong within the genus Pseudoalteromonas, but are distinct from other recognized Pseudoalteromonas species described thus far. Considering also the phylogenetic and DNA-DNA hybridization data, we propose that the name of this novel species 
should be Pseudoalteromonas marina sp. nov., and that strain $\operatorname{mano} 4^{\mathrm{T}}$ should be designated as the type strain.

Ivanova et al. (2000, 2002a, b, c, d, e, 2004b) have extensively explored the diversity and systematics of the genus Pseudoalteromonas. In successive studies, they observed that Pseudoalteromonas bacteriolytica Sawabe et al. 1998 (basonym of Algicola bacteriolytica) branched deeply in the phylogenetic tree of the genus and lacked a signature sequence (Ivanova et al., 2004a). Thus, the genus Algicola has been newly proposed to resolve the phylogenetic relationships among the marine Alteromonas-like proteobacteria. However, Pseudoalteromonas sagamiensis (Kobayashi et al., 2003), which is the species most closely related to Algicola bacteriolytica, was not included in the study. The $16 \mathrm{~S}$ rRNA gene sequences of members of the genera Pseudoalteromonas and Algicola and a related species were retrieved from the NCBI database. DNA sequence alignment was conducted using CLUSTAL_X software (Thompson et al., 1997). Phylogenetic trees were constructed using the Fitch \& Margoliash (Fitch \& Margoliash, 1967) and neighbour-joining (Saitou \& Nei, 1987) methods. The resultant unrooted tree topology was evaluated by bootstrap analysis based on 1000 resamplings (Felsenstein, 1985), using the neighbour-joining method. From the unrooted evolutionary tree shown in Fig. 1, we concluded that $P$. sagamiensis forms a branch with Algicola bacteriolytica that is distinct from other Pseudoalteromonas species. The relationship is based on data from different tree-making algorithms and the bootstrap value of $100 \%$. $P$. sagamiensis showed very low sequence similarity $(90.4 \%)$ to
Algicola bacteriolytica. Despite this low similarity, Kobayashi et al. (2003) did not classify $P$. sagamiensis as representing a new genus because the phenotypic differences between $P$. sagamiensis and currently known related genera seemed too small to warrant generic separation.

P. sagamiensis can also be clearly differentiated by phenotypic characteristics determined in previous studies (Ivanova et al., 2004a; Kobayashi et al., 2003; Sawabe et al., 1998). As shown in Table 2, P. sagamiensis and Algicola bacteriolytica showed low halotolerance, in contrast to the other Pseudoalteromonas species. They also shared the characteristic of lack of growth at 4 and $37^{\circ} \mathrm{C}$. However, some phenotypic properties, such as bacteriolytic activity and utilization of D-mannose, D-fructose and sucrose, differentiated $P$. sagamiensis from Algicola bacteriolytica.

Given the polyphasic data from an earlier study (Romanenko et al., 1995) and the data presented here, we propose that Pseudoalteromonas sagamiensis Kobayashi et al. 2003 be reassigned to the genus Algicola as Algicola sagamiensis comb. nov.

\section{Description of Pseudoalteromonas marina sp. nov.}

Pseudoalteromonas marina (ma.ri'na. L. fem. adj. marina of the sea, marine).

Cells are Gram-negative, rod-shaped on MA (measuring $0.5-0.7 \times 2.1-3.0 \mu \mathrm{m})$ and motile. Cells do not form endospores. Colonies are pale yellow in colour,

Table 2. Differential characteristics of members of the family Pseudoalteromonadaceae

+, Positive; -, negative; +/-, variable reaction; v, reaction varies between strains. Data from Ivanova et al. (2004a), Kobayashi et al. (2003) and Sawabe et al. (1998). All taxa are negative for flagella outer coat.

\begin{tabular}{|c|c|c|c|}
\hline Characteristic & Genus Pseudoalteromonas & Algicola bacteriolytica & Pseudoalteromonas sagamiensis \\
\hline Pigmentation & $+1-$ & + & + \\
\hline \multicolumn{4}{|l|}{ Flagellation: } \\
\hline Bipolar & $+1-$ & - & - \\
\hline Lateral & $+1-$ & - & - \\
\hline Halotolerance (\% NaCl) & 15 & 6 & 5 \\
\hline \multicolumn{4}{|l|}{ Growth at: } \\
\hline $4^{\circ} \mathrm{C}$ & + & - & - \\
\hline $37{ }^{\circ} \mathrm{C}$ & + & - & - \\
\hline \multicolumn{4}{|l|}{ Hydrolysis of: } \\
\hline Chitin & $\mathrm{V}$ & - & - \\
\hline Starch & $\mathrm{V}$ & + & + \\
\hline \multicolumn{4}{|l|}{ Utilization of: } \\
\hline D-Fructose & $\mathrm{V}$ & + & - \\
\hline D-Mannose & $\mathrm{V}$ & + & - \\
\hline Sucrose & $\mathrm{V}$ & + & - \\
\hline Glycerol & $\mathrm{V}$ & - & - \\
\hline Lactose & $\mathrm{V}$ & - & - \\
\hline DNA G + C content $(\mathrm{mol} \%)$ & $37-50$ & $44-46$ & 42 \\
\hline
\end{tabular}


$0.2-0.5 \mathrm{~mm}$ in diameter, smooth and circular to slightly irregular in shape after 3 days of culture on MA. Growth occurs at $4-37^{\circ} \mathrm{C}$ and at $\mathrm{pH} 5.3-8.8$, but not at $\mathrm{pH}$ values lower than 4.1 nor higher than 9.3. Growth occurs in the presence of $3-12 \% \mathrm{NaCl}$, but not in the absence of $\mathrm{NaCl}$ or in $15 \% \mathrm{NaCl}$. Growth is not observed under anaerobic conditions. Catalase-positive and Voges-Proskauer test negative. Casein and starch are hydrolysed, but nitrate is not reduced to nitrite. Produce amylase, caseinase, alginase, DNase, but not agarase or chitinase, and utilize glucose, maltose and melibiose as a sole carbon and energy source. The following substrates are not utilized: D-arabinose, L-arginine, D-galactose, lactose, D-mannitol, sorbitol, citrate and xylose. Major fatty acids are $\mathrm{C}_{15: 0}(6.8 \pm 0.4 \%), \mathrm{C}_{16: 0}(21.3 \pm 0.7 \%)$ and $\mathrm{C}_{16: 1} \omega 7 c(24.7 \pm 1.2 \%)$.

The DNA G + C content of the type strain is $41.2 \mathrm{~mol} \%$. The type strain, $\operatorname{mano}^{\mathrm{T}}\left(=\right.$ KCTC $\left.12242^{\mathrm{T}}=\mathrm{DSM} 17587^{\mathrm{T}}\right)$, was isolated from a tidal flat area of Dae-Chun, Chung-Nam, Korea.

\section{Description of Algicola sagamiensis Kobayashi et al. 2003 comb. nov.}

Algicola sagamiensis (sa.ga.mi.en'sis. N.L. fem. adj. sagamiensis referring to Sagami Bay, the place of isolation).

Basonym: Pseudoalteromonas sagamiensis Kobayashi et al. 2003. The description is identical to that given by Kobayashi et al. (2003).

The type strain is B-10-31 ${ }^{\mathrm{T}}\left(=\mathrm{DSM} 14643^{\mathrm{T}}=\mathrm{JCM} 11461^{\mathrm{T}}\right)$.

\section{Acknowledgements}

The authors are supported by grant BDM0200524, NNM0100512, KRIBB Research Initiative Program and Environmental Biotechnology National Core Research Center (KOSEF: R15-2003-012-02002-0), from the Ministry of Science and Technology (MOST) of the Republic of Korea.

\section{References}

Bae, J. W., Rhee, S. K., Nam, Y. D. \& Park, Y. H. (2005). Generation of subspecies level-specific microbial diagnostic microarrays using genes amplified from subtractive suppression hybridization as microarray probes. Nucleic Acids Res 33, e113.

Egan, S., Holmström, C. \& Kjelleberg, S. (2001). Pseudoalteromonas ulvae sp. nov., a bacterium with antifouling activities isolated from the surface of a marine alga. Int J Syst Evol Microbiol 51, 1499-1504.

Felsenstein, J. (1985). Confidence limits on phylogenies: an approach using the bootstrap. Evolution 39, 783-791.

Fitch, W. M. \& Margoliash, E. (1967). Construction of phylogenetic trees. Science 155, 279-284.

Gauthier, G., Gauthier, M. \& Christen, R. (1995). Phylogenetic analysis of the genera Alteromonas, Shewanella, and Moritella using genes coding for small-subunit rRNA sequences and division of the genus Alteromonas into two genera, Alteromonas (emended) and Pseudoalteromonas gen. nov., and proposal of twelve new species combinations. Int J Syst Bacteriol 45, 755-761.
Gordon, R. E., Haynes, W. C. \& Pang, C. H. (1973). The Genus Bacillus. Washington, DC: USDA.

Isnansetyo, A. \& Kamei, Y. (2003). Pseudoalteromonas phenolica sp. nov., a novel marine bacterium that produces phenolic antimethicillin-resistant Staphylococcus aureus substances. Int J Syst Evol Microbiol 53, 583-588.

Ivanova, E. P., Chun, J., Romanenko, L. A., Matte, M. E., Mikhailov, V. V., Frolova, G. M., Huq, A. \& Colwell, R. R. (2000). Reclassification of Alteromonas distincta Romanenko et al. 1995 as Pseudoalteromonas distincta comb. nov. Int J Syst Evol Microbiol 50, 141-144.

Ivanova, E. P., Gorshkova, N. M., Sawabe, T., Hayashi, K., Kalinovskaya, N. I., Lysenko, A. M., Zhukova, N. V., Nicolau, D. V., Kuznetsova, T. A. \& other authors (2002a). Pseudomonas extremorientalis sp. nov., isolated from a drinking water reservoir. Int J Syst Evol Microbiol 52, 2113-2120.

Ivanova, E. P., Sawabe, T., Alexeeva, Y. V., Lysenko, A. M., Gorshkova, N. M., Hayashi, K., Zukova, N. V., Christen, R. \& Mikhailov, V. V. (2002b). Pseudoalteromonas issachenkonii sp. nov., a bacterium that degrades the thallus of the brown alga Fucus evanescens. Int J Syst Evol Microbiol 52, 229-234.

Ivanova, E. P., Sawabe, T., Lysenko, A. M., Gorshkova, N. M., Hayashi, K., Zhukova, N. V., Nicolau, D. V., Christen, R. \& Mikhailov, V. V. (2002c). Pseudoalteromonas translucida sp. nov. and Pseudoalteromonas paragorgicola sp. nov., and emended description of the genus. Int J Syst Evol Microbiol 52, 1759-1766.

Ivanova, E. P., Sawabe, T., Lysenko, A. M., Gorshkova, N. M., Svetashev, V. I., Nicolau, D. V., Yumoto, N., Taguchi, T., Yoshikawa, S. \& other authors (2002d). Pseudoalteromonas ruthenica sp. nov., isolated from marine invertebrates. Int J Syst Evol Microbiol 52, 235-240.

Ivanova, E. P., Shevchenko, L. S., Sawabe, T., Lysenko, A. M., Svetashev, V. I., Gorshkova, N. M., Satomi, M., Christen, R. \& Mikhailov, V. V. (2002e). Pseudoalteromonas maricaloris sp. nov., isolated from an Australian sponge, and reclassification of [Pseudoalteromonas aurantia] NCIMB 2033 as Pseudoalteromonas flavipulchra sp. nov. Int J Syst Evol Microbiol 52, 263-271.

Ivanova, E. P., Flavier, S. \& Christen, R. (2004a). Phylogenetic relationships among marine Alteromonas-like proteobacteria: emended description of the family Alteromonadaceae and proposal of Pseudoalteromonadaceae fam. nov., Colwelliaceae fam. nov., Shewanellaceae fam. nov., Moritellaceae fam. nov., Ferrimonadaceae fam. nov., Idiomarinaceae fam. nov. and Psychromonadaceae fam. nov. Int J Syst Evol Microbiol 54, 1773-1788.

Ivanova, E. P., Gorshkova, N. M., Zhukova, N. V., Lysenko, A. M., Zelepuga, E. A., Prokof'eva, N. G., Mikhailov, V. V., Nicolau, D. V. \& Christen, R. (2004b). Characterization of Pseudoalteromonas distincta-like sea-water isolates and description of Pseudoalteromonas aliena sp. nov. Int J Syst Evol Microbiol 54, 1431-1437.

Kim, B. S., Oh, H. M., Kang, H., Park, S. S. \& Chun, J. (2004). Remarkable bacterial diversity in the tidal flat sediment as revealed by $16 \mathrm{~S}$ rDNA analysis. J Microbiol Biotechnol 14, 205-211.

Kobayashi, T., Imada, C., Hiraishi, A., Tsujibo, H., Miyamoto, K., Inamori, Y., Hamada, N. \& Watanabe, E. (2003). Pseudoalteromonas sagamiensis sp. nov., a marine bacterium that produces protease inhibitors. Int J Syst Evol Microbiol 53, 1807-1811.

Lau, S. C. K., Tsoi, M. M. Y., Li, X., Dobretsov, S., Plakhotnikova, Y., Wong, P.-K. \& Qian, P.-Y. (2005). Pseudoalteromonas spongiae sp. nov., a novel member of the $\gamma$-Proteobacteria isolated from the sponge Mycale adhaerens in Hong Kong waters. Int J Syst Evol Microbiol 55, 1593-1596.

Romanenko, L. A., Mikhailov, V. V., Lysenko, A. M. \& Stepanenko, V. I. (1995). A new species of melanin-producing bacteria of the genus Alteromonas. Mikrobiologiia 64, 74-77 (in Russian). 
Romanenko, L. A., Zhukova, N. V., Lysenko, A. M., Mikhailov, V. V. \& Stackebrandt, E. (2003a). Assignment of 'Alteromonas marinoglutinosa' NCIMB 1770 to Pseudoalteromonas mariniglutinosa sp. nov., nom. rev., comb. nov. Int J Syst Evol Microbiol 53, 1105-1109.

Romanenko, L. A., Zhukova, N. V., Rohde, M., Lysenko, A. M., Mikhailov, V. V. \& Stackebrandt, E. (2003b). Pseudoalteromonas agarivorans sp. nov., a novel marine agarolytic bacterium. Int J Syst Evol Microbiol 53, 125-131.

Saitou, N. \& Nei, M. (1987). The neighbour-joining method: a new method for reconstructing phylogenetic trees. Mol Biol Evol 4, 406-425.

Sambrook, J., Fritsch, E. F. \& Maniatis, T. (1989). Molecular Cloning: a Laboratory Manual, 2nd edn. Cold Spring Harbor, NY: Cold Spring Harbor Laboratory.
Sasser, M. (1990). Identification of bacteria by gas chromatography of cellular fatty acids, MIDI Technical Note 101. Newark, DE: MIDI Inc.

Sawabe, T., Makino, H., Tatsumi, M., Nakano, K., Tajima, K., Iqbal, M. M., Yumoto, I., Ezura, Y. \& Christen, R. (1998). Pseudoalteromonas bacteriolytica sp. nov., a marine bacterium that is the causative agent of red spot disease of Laminaria japonica. Int J Syst Bacteriol 48, 769774 .

Tamaoka \& Komagata (1984). Determination of DNA base composition by reverse-phase high-performance liquid chromatography. FEMS Microbiol Lett 25, 125-128.

Thompson, J. D., Gibson, T. J., Plewniak, F., Jeanmougin, F. \& Higgins, D. G. (1997). The CLUSTAL_X windows interface: flexible strategies for multiple sequence alignment aided by quality analysis tools. Nucleic Acids Res 25, 4876-4882. 